\title{
Promotion of Improved Management of Sorghum for Small Scale Farmers in North Gondar, Gondar Zuria District
}

\author{
Simachew Yedemie* and Yonas Worku \\ Gondar Agricultural Research Center Gondar, Ethiopia \\ *Corresponding author: Simachew Yedemie, Gondar Agricultural Research Center Gondar, Ethiopia \\ Submission: 眥 March 05, 2018; Published: 望 April 26, 2018
}

\begin{abstract}
Pre scale up of sorghum improved management was conducted far from 46km from Gondar city at Degola Chinchaye and Das Denzaz kebele of Gondar Zuria district in 2016/2017 production season. This farm size was 5 hectares in each Keble on 26 ( 1 female and 25 male) farmers and those clients were participated from planting to yield evaluation. This improved management was Fertilizer application, ridging and tie-ridging, thinning and all agronomic practices. The seed rate was $12 \mathrm{~kg} / \mathrm{ha} .112 \mathrm{~kg} / \mathrm{ha}$ NPS was applied at planting whereas $150 \mathrm{~kg} / \mathrm{ha}$ urea was applied $(87 \mathrm{~kg} / \mathrm{ha}$ of N with split application $1 / 2$ at planting, $1 / 2$ at knee height /after first weeding. All other agronomic practices and farm operation were done by farmers based on the recommendation with close assistance from development agents and respective researchers.
\end{abstract}

Training was given for one day about sorghum improved management and production package for farmers, development agents and district level agricultural experts. Field day and experience sharing was organized and 288 (farmers, extension workers, NGOs, Journalists and Researchers) were participated during the field day and experience sharing. Grand mean grain yield was 3.47ton/ha and about three thousand farmers respond to this technology in one district. This Technology should be Scale out other districts which have the same problems and agro ecology.

Keywords: Farmers research and extension groups; Field day; Training; Workshop

\section{Introduction}

Sorghum (sorghum bicolor L.) common name for corn like grasses native to Africa and Asia, where they have been cultivated since ancient times. Grain sorghum, are the staple food for millions of people in china, India and Africa Alagarswamy [1] sorghum is one of the major crops grown in high, intermediate and low elevation areas of Ethiopia. It can also adapt conditions that are unfavorable for most of the other cereal crops.

In the study area, North Gondar, sorghum covers large amount of the cultivated area and is being produced as a major crop in many peasant associations, regardless of the production system, the improved or local seed used, the utilization and marketing patterns and the like [2]. Most of small holder farmers, in those areas, are dependent on it for food and source of cash for the household. Moreover, the stalk and other by-products of sorghum are major source of animal feed, fuel and construction materials. It can also be used to make traditional homemade beverages and juicy stalks are commonly chewed like sugar cane [3].

Despite its importance as the source of food and cash for resource poor and smallholder farmers, farmers produce sorghum traditional. The average yield per unit area of sorghum in Ethiopia is not more than 1.0t/ha CSA [4], which is below the world average of 2.3t/ha [5]. Farmers seldom apply fertilizer to sorghum. This is partly because, sorghum is one of grown under marginal conditions, resulting in relatively low yields and partly due to the fact that fertilizer prices are unfavorably high in relation to sorghum price. However, sorghum responds to applied fertilizers and can increase yield by over 50\%. To verify this fact Gondar Agricultural Research Center has tasted fertilizer rate determination trial on sorghum productivity and demonstrated at Gondar Zuria district.

The result of the study showed that a yield of $4 \mathrm{t} / \mathrm{h}$ a was obtained at $87 \mathrm{~kg} / \mathrm{ha}$ of $\mathrm{N}$ with split application $1 / 2$ at planting, $1 / 2$ at knee height and in addition to this Farmer-Research-Extension-Groups (FREG) was formed to facilitate farmers' genuine participation in local and improved management practice selection process. FREG members selected sorghum improved management practice for wide scale production. Sorghum improved management was totally preferred and widely promoted in 2016/2017 production season. In order to increase the production and productivity of sorghum in the area, we were pre scale up such promising technology. 


\section{Objective}

a) To create a wider demand on Sorghum management technology

b) To create and strengthen linkage among stake holders.

c) To enhance technology multiplication and dissemination.

\section{Materials and Methods}

Pre scale up of sorghum improved management was conducted far from 46km from Gondar city at Degola Chinchaye and Das Denzaz kebele of Gondar Zuria district in 2016/2017 production season. The farm size was 5 hectare in each Keble on 26 ( 1 female and 25 male) farmers and those clients were participated from planting to yield evaluation. This improved management was Fertilizer application, ridging and tie-ridging, thinning and all agronomic practices. The seed rate was $8 \mathrm{~kg}-12 \mathrm{~kg} / \mathrm{ha} .112 \mathrm{~kg} / \mathrm{ha}$ NPS was applied at planting whereas $150 \mathrm{~kg} / \mathrm{ha}$ urea was applied (87kg/ha of $\mathrm{N}$ with split application $1 / 2$ at planting, $1 / 2$ at knee height/after first weeding.

All other agronomic practices were done by farmers based on the recommendation with close assistance from development agents and researchers. All farm operations were carried out by farmers with close assistance and supervision from respective Table 1: Field day participant's feedback. researchers. Training was given for one day about sorghum improved management and production package for farmers, development agents and district level agricultural experts before planting. Farmers' field days were organized and farmers, extension workers, other development workers, multidisciplinary team of researchers and district level policy makers have participated. Grain yield and biomass data were collected using two by two meter quadrant from each participant farmer's plot and secondary data was gathered from neighboring farmers' field. Simple descriptive statistics were used to do analysis.

\section{Result and Discussion}

\section{Training}

Training was given for one day about sorghum improved management and production package for 30 farmers $(29$ male and 1 female), 10 development agents and 2 district level agricultural experts before planting.

\section{Field day}

GARC was organized field day at the time of maturity. During the field day farmers, extension workers, other development workers, multidisciplinary team of researchers and district experts, journalists, Fana FM 98.1 radio and Ethiopian television service were participated (Table 1).

\begin{tabular}{|c|c|c|c|c|c|c|c|c|c|}
\hline \multicolumn{2}{|c|}{ GARC } & \multicolumn{2}{|c|}{ Zonal level } & \multicolumn{2}{c|}{ District level } & \multicolumn{2}{c|}{ Development Agent } & \multicolumn{2}{c|}{ Farmers } \\
\hline M & F & M & F & M & F & M & F & M & F \\
\hline 15 & 4 & 3 & 2 & 3 & 1 & 4 & 6 & 94 & 64 \\
\hline
\end{tabular}

\begin{tabular}{|c|c|c|c|c|c|c|c|c|c|c|}
\hline \multicolumn{2}{|c|}{ GARC } & \multicolumn{2}{|c|}{ Zonal level } & \multicolumn{2}{|c|}{ District level } & \multicolumn{2}{|c|}{ Development Agent } & \multicolumn{2}{|c|}{ farmers } & Total \\
\hline M & $\mathrm{F}$ & M & $\mathrm{F}$ & M & $\mathrm{F}$ & M & $\mathrm{F}$ & M & $\mathrm{F}$ & \\
\hline 4 & - & 8 & 1 & 5 & - & 18 & 24 & 38 & 2 & 100 \\
\hline
\end{tabular}

\section{Field day participant's feedback}

a) We see such like performance before 15 years when the soil fertility was good.

b) We have applied sorghum improved management especially fertilizer application and ridging after the intervention of GARC.

c) High fertilizer price and does not supply on time are the main challenges to perform sorghum improved management.

d) This technology is important not only yield advantage but also save seed more than broadcast planting method.

e) Improved sorghum management helps to decrease the rate of weed for the next year.

f) This technology is important to conserve soil fertility.

g) It helps to strengthening social relationship since it pushes work together.

GARC was organized exit workshop; due to this experience sharing was conducted for two districts which have the same agro ecology (Table 2).

Table 2: Experience sharing participant's feedback.

\begin{tabular}{|c|c|c|c|c|c|c|c|c|c|c|c|c|c|}
\hline Site & 1 & 2 & 3 & 4 & 5 & 6 & 7 & 8 & 9 & 10 & 11 & 12 & 13 \\
\hline $\begin{array}{c}\text { Grain Yield } \\
\text { kg/ha }\end{array}$ & 4887.5 & 3312.5 & 3600 & 3750 & 3525 & 3712.5 & 2031.25 & 2687.5 & 3887.75 & 3368.75 & 2743.75 & 3437.5 & 3787.75 \\
\hline $\begin{array}{c}\text { Mean Grain } \\
\text { Yield }\end{array}$ & & & & & & & 3465.62 & & & & & & \\
\hline
\end{tabular}




\section{Experience sharing participant's feedback}

a) No debate to adopt this technology.

b) Before planting training will be necessary.

\section{Yield}

Sorghum improved management has been promoted to Das denzaz and Degola chinchaye farmers in 2016 production season. It was intended to replace local practice widely being used by farmers, which is low production. Samples were collected from 26 farmers plot and the grain yield of sorghum improved management was as follows.

\section{Conclusion and Recommendation}

a) Improve management was high yielder than local practice.

b) Farmers were challenged by high fertilizer price and supply on time.

c) From the study we understood fertilizer application, ridging and tie-ridging, thinning control of weed that labor utility for sorghum improved management is easy, and the yield could cover the extra costs incurred for labor as we have seen in pre extension demonstration.

d) In our study the main challenge were high fertilizer price and unavailability on time so the administrative should be permit credit and supply on time.

e) Finally considering different important aspects of the technology (farmers and others take holders feedback and perception, mean grain yield and time of maturity) sorghum improved should be promoted and scale out to other districts which grow sorghum and which have the same problems.

\section{References}

1. Alagarswamy (1992) Food stable of sorghum grain in China, India and Africa.

2. ARARI (2002) Sorghum production in Amhara region state.

3. Aleligne (1996) Importance of sorghum grain and its stalk.

4. CSA (2000) Area clustering of sorghum production, area coverage and Productivity.

5. Benti (1993) Experience of farmer's application fertilizer on Sorghum
Creative Commons Attribution 4.0 International License

For possible submissions Click Here

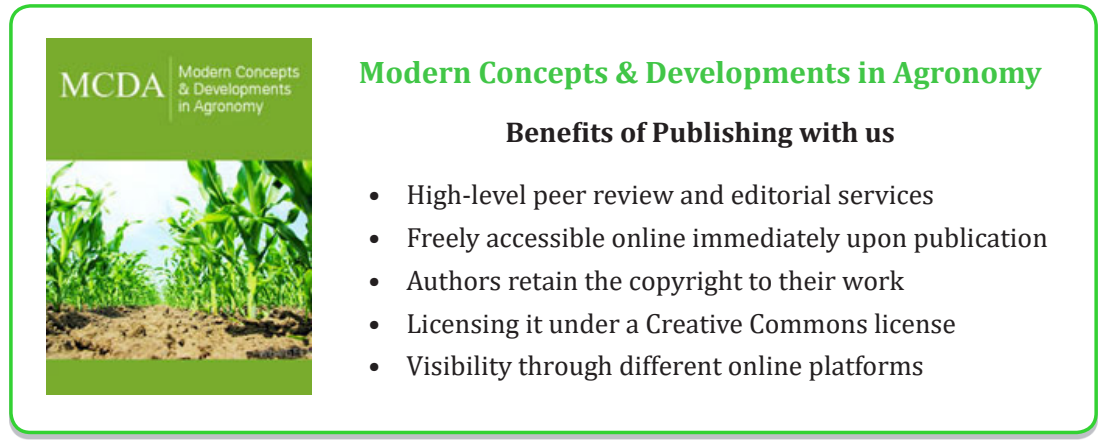

